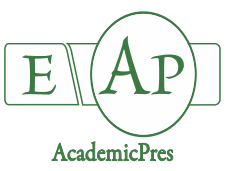

Janick J (2020)
$\begin{gathered}\text { Notulae Botanicae Horti Agrobotanici Cluj-Napoca 48(3):1116-1129 } \\ \text { DOI: } 10.15835 / \text { nbha48312015 } \\ \text { Research Article }\end{gathered}$

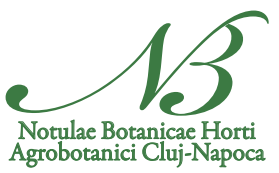

\title{
Iconography of domesticated sunflower
}

\author{
Jules JANICK
}

Purdue University, Department of Horticulture \& Landscape Architecture, West Lafayette IN 47907-2010,

USA; janick@purdue.edu

\begin{abstract}
Sunflower (Helianthus annuus L.) is indigenous to the New World with domesticated types characterized by a single stem with a large seed head. Archeological evidence has indicted that domestication occurred in the Eastern United States. However, images of domesticated sunflower are found in a pre-Hispanic Aztec stone sculpture, various $16^{\text {th }}$ century images from New Spain (present day Mexico), and $16^{\text {th }}$ century European herbals based on imported seed. Iconographic, linguistic, and archaeological evidence confirm that the domesticated types were known by the Aztec previous to the conquest of Cortés in 1522. This evidence suggests either an independent domestication of sunflower in Mexico or a pre-Hispanic migration from North America.
\end{abstract}

Keywords: domestication; iconography; Helianthus annuus; Mexico; New Spain, sunflower

\section{Introduction}

The sunflower (Helianthus annuus L.) is the third most important world oilseed. World oilseed production in millions of tonnes for 2019/2020 was soybean (337.5), rapeseed (44.3), sunflower (53.5), peanut (44.5), and African oil palm kernel (20.0) (www.statista.com). Sunflower seed oil is used for cooking, margarine, salad dressings, lubrication, soaps, illumination and as a component of paints and varnishes (Duke, 1983). Decorticated press-cake is used as a high protein food for livestock. Sunflower seed is widely used for wild and caged birds, raw or roasted salted kernels are a popular snack food, and hulls provide filler in livestock feeds and bedding. Plants are used for fodder and silage. Major producers are Ukraine, Russia, Argentina, China, and Romania (Pilorgé, 2020).

Spanish explorers introduced the sunflower to Europe but the date and source of the first introduction is unclear. According to Zukovsky (1950) sunflower seed obtained by a Spanish expedition to "New Mexico" in 1510 was planted in a Madrid garden and then spread rapidly throughout Europe. This assertion is unlikely since the first European to have reached what is now New Mexico was Alvar Nunex Cabez de Vaca about 1535 (Heiser, 1998). An early date for the presence of sunflower in Spain is given by Nicolas Monardes (1574) who writes in the third book "Of the Yerba del Sol... there are some years we have it here... it seems very good in gardens." The European encounter with the extraordinary sunflower caused a sensation to gardeners and artists (Mancoff, 2001). All European sunflower paintings show the large-headed, single-stemmed, domesticated form (Figure 1). The sunflower was prized as an ornamental rather than a food plant in Europe until it reached 
Russia in the 1800s where genetic improvement into an oil crop began around 1860. By the late 1940s, Americans brought back sunflower cultivars from the Soviet Union with an oil content reaching nearly 50\%.
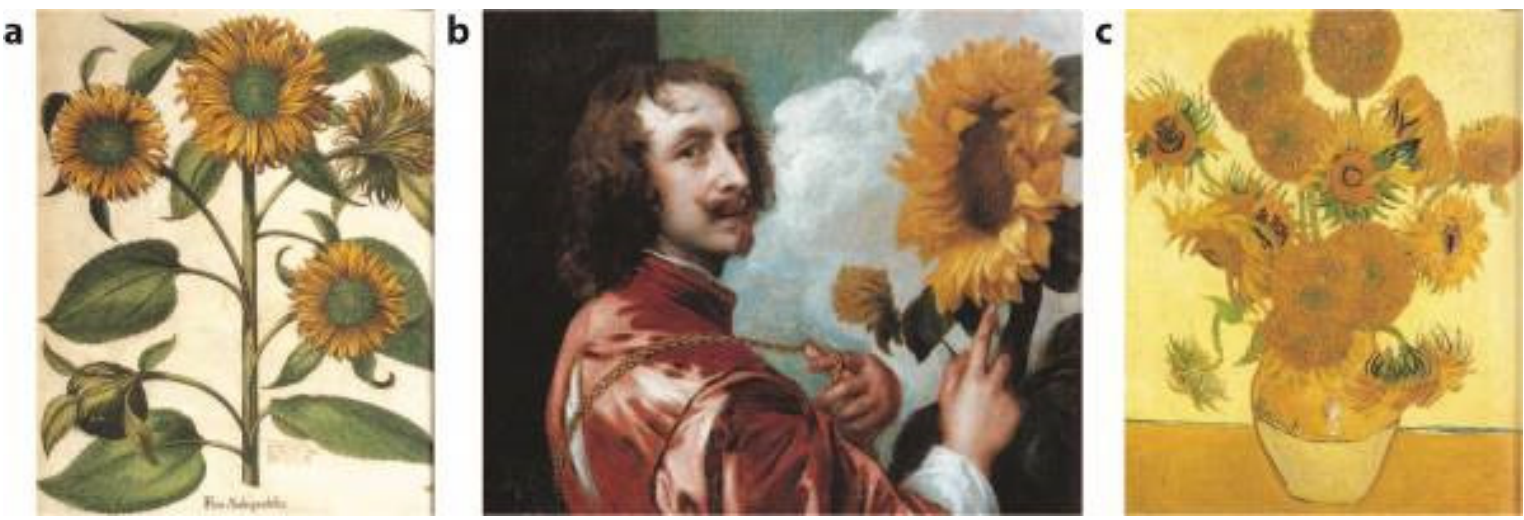

Figure 1. Famous European illustration of sunflower: (a) Asilius Besler, 1613; (b) Antony Van Dyke, 1654;

(c) Vincent Van Gogh, 1888

Source: Mancoff (2001)

\section{Domestication of the sunflower}

Helianthus annuus is indigenous to the New World (Heiser, 1955; 1976) but the origin of domestication is controversial. Wild sunflower, a common roadside weed in the United States (Figure 2 right), is a branched herb with many small asterid heads (discs) and small seed. Domesticated types (Figure 2 left) are single-stemmed, monocephalic - typically bearing a single large seed head with large seed that lacks dormancy. Evidence that sunflower was domesticated in Eastern North America is supported by abundant archeological evidence. Heiser (1951) admitted that sunflower was common in New Spain in the $16^{\text {th }}$ century but later (Heiser, 1998) denied that domesticated sunflower appeared in Mexico prior to the Spanish incursion. However, Lentz et al. (2008) presents archaeological, historical, and linguistic evidence that support an earlier independent domestication in Mexico. The strongest archeological evidence was based on three achenes unearthed from a dry cave from Cueva del Gallom, Morelos, Mexico (dated 290 +/- 40 BCE). Achene length $(11 \mathrm{~mm})$ and width $(5.5 \mathrm{~mm})$ was larger than those found in domesticates from archeological sites in eastern North American and was within the range of US indigenous domesticates. The controversy over the origins of sunflower has led to spirited published debate (Heiser and Lentz, 2008).

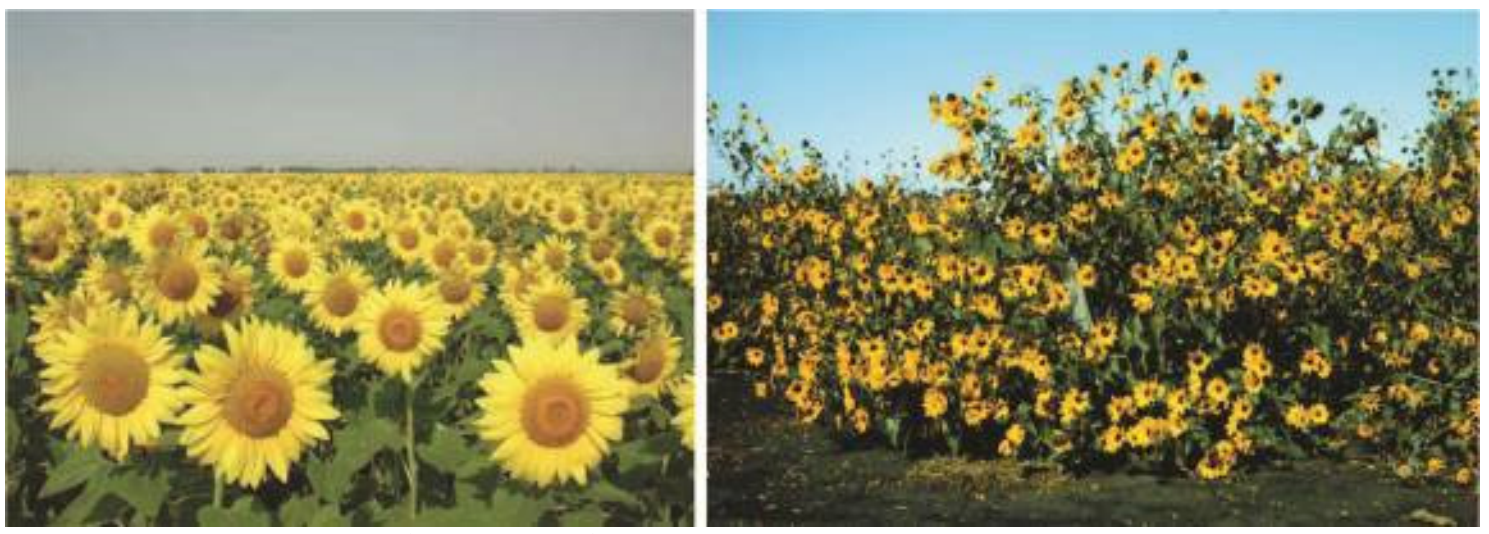

Figure 2. Domesticated (left) and wild (right) sunflower Source: Seiler and Gulya (2016) 
There are basically two viable possibilities: (1) domestication occurred only in North America and domesticated types moved to Mexico via pre-Hispanic trade routes; (2) domestication of sunflower occurred independently in Mexico. The objective of this paper is to attempt to differentiate these alternatives through iconography from historic Mexican and European sources.

\section{Linguistics}

There are various indigenous names for sunflower in Mexico. The basic Nahuatl names for sunflower are chimalacatl (shield reed) or chimalxochitl (shield flower) based on the resemblance of the large discs to shields (chimalli) used by Aztec warriors. Consequently, symbolized images of sunflower heads became a metaphor for warfare and sunflowers with tassels affixed to the base of the stout stem were often presented as gifts along with tobacco pipes which resembled spears. The word chimalacatlis first found in the dictionary of Fray Alonso de Molina (1571:300), Franciscan priest and grammarian, who defined it as "cierta y erua [erva] grande y redonda" i.e. certain, large and round herb.

The Spanish names, girasol (from girar, to turn) or mirasol (from mirar, to watch) are based on the heliotropic movement of the plant. Young shoots and immature flower buds track the sun during the day due to phototropic movement of the sunflower stem but mature flowers constantly face east (Kutschera and Briggs, 2016).

The Latin name used in herbals, Flos soli (sun flower) is based on the resemblance of the seed head to images of the sun. The modern Otomi name da nukua meaning "big flower that looks at the Sun God" (Lentz et al., 2008).

\section{Iconography}

There are numerous historic images of sunflower. The earliest is a pre-Hispanic stone sunflower head from Mexico. There are various $16^{\text {th }}$ century illustrations from New Spain and Europe. These include a 12volume work known as the Florentine Codex written by Bernardino de Rivera between 1540 and 1585; the European herbal of Rembert Dodoens published in 1568, the Voynich Codex estimated to be written in New Spain between 1568-1572; botanical works of Francisco Hernandez based on paintings of indigenous painters in New Spain between 1570 and 1577; the Codex Duran (1581); the Codex Ixtlixochitl (1584); the English herbal of John Gerard $(1597,1633)$, and a 1590 engraving by Theodore de Bry of a scene from what is now known as North Carolina.

\section{Aztec images of sunflower}

A pre-Hispanic stone sculpture of a sunflower head representing the goddess Xochiquetzelkept at the National Anthropology Museum in Mexico City (Figure 3) provides evidence for the pre-Columbian presence of domesticated sunflower in Mexico. Sunflower images labeled chimalacatylare found in the codex Histoira genera de las cosas de la Nueva Espana (General History of the Things of New Spain) by the Franciscan friar Bernadino de Rivera (1499-1590). Born in Sahagún, Spain, he is generally referred to as simply Sahagún. He arrived in New Spain in 1529 as one of was one of the 12 apostles to instruct and convert the indigenous population. Sahagún learned Nahuatl, and became the premier ethnologist of Nahuan (Aztec) culture and history. He was a founder and served as Dean as of the Colegio de Santa Cruz in Tlatelolco, an institution established to train sons of the Aztec nobility to become priests. Sahagún's 12-volume work of 2400 pages and 2468 illustrations completed in 1569 in Nahuatl and Spanish was found in Italy is often referred to as the Florentine Codex. Indigenous artists made the illustrations. Book 9 (Merchants) contains symbolic images of domesticated sunflower (Figure 4). Book 11 (Earthly Things, illustration 757) shows a small-headed, branched 
plant referred to as chimalacatl that resembles a wild sunflower or hybrid between wild and a domesticate (Figure 5). Heiser (2008) defending his belief that domestication did not occur in Mexico expresses doubts that Aztec illustration in Sahagun's Merchants were sunflower and notes that Hernandez refers to more than one plant named chimalacatl. Lentz (2008) responded that these drawings of native artists were often symbolic and not completely descriptive as found in Western botanical illustration.

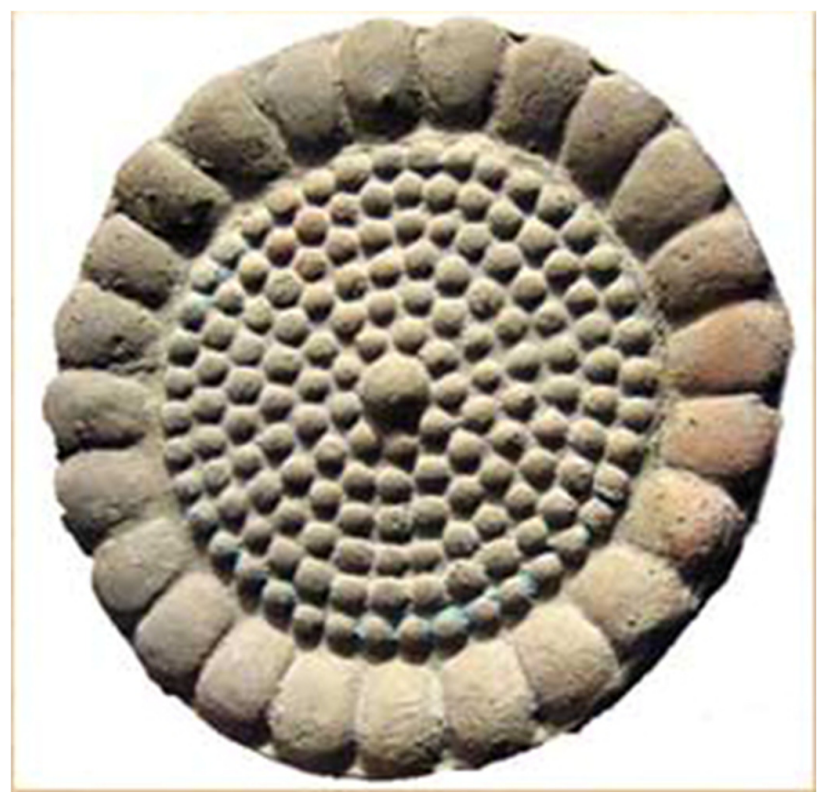

Figure 3. Pre-Hispanic stone sculpture of sunflower head Source: National Museum of Anthropology in Mexico City, Mexico, https://www.mexicolore.co.uk/aztecs/flora-andfauna/sunflower

In the History of the Indies of New Spain (1581) by the Dominican friar Diego Durán, also known as the Codex Durán, an illustration shows a tasseled symbolic sunflower presented as a gift to Spanish soldiers by a native inhabitant of Tlaxcala (Figure 6). In the Codex IxtlixochitI (1584), the poet king Netzahualpilli, (1464-1515), ruler of Tetzcoco after the death of his father Netzahualcóyotl in 1476 holds a yellow and red sunflower bud and open sunflower, both tasseled (Figure 7). 


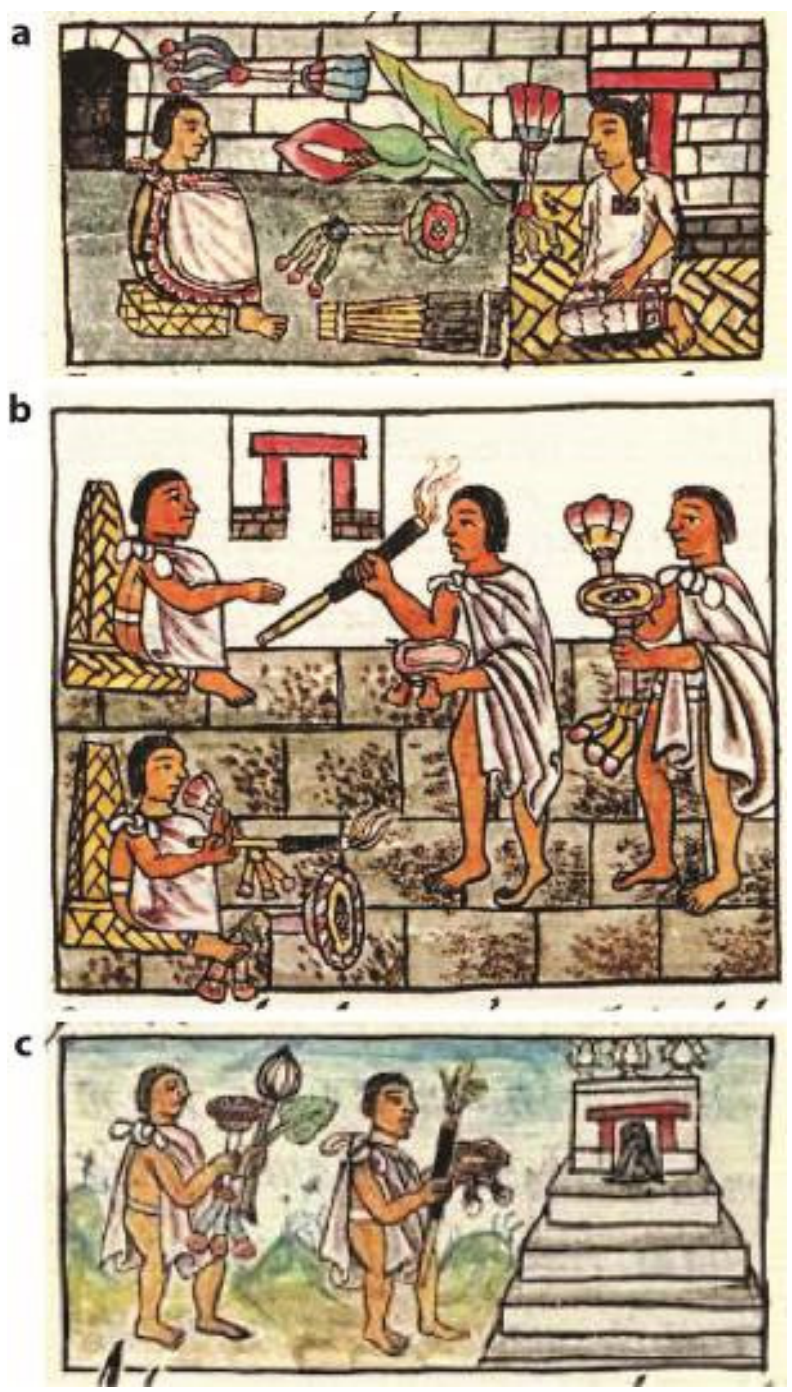

Figure 4. Aztec images from the Florentine Codex, Book 9 (Merchants). Presentation of sunflower (chimalacat) with tassels on stem and tobacco pipes

Source: Sahagún (1951-1982), https://www.mexicolore.co.uk/aztecs/flora-and-fauna/sunflower

Figure 5. Wild sunflower (chimalacat)

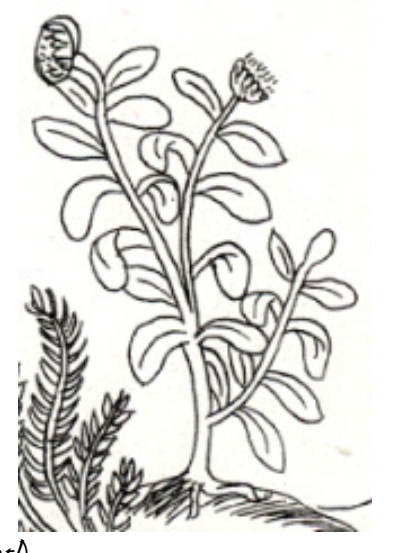

Source: image 757 of Book 11 (Earthly Things) of Sahagún (1951-1982). 


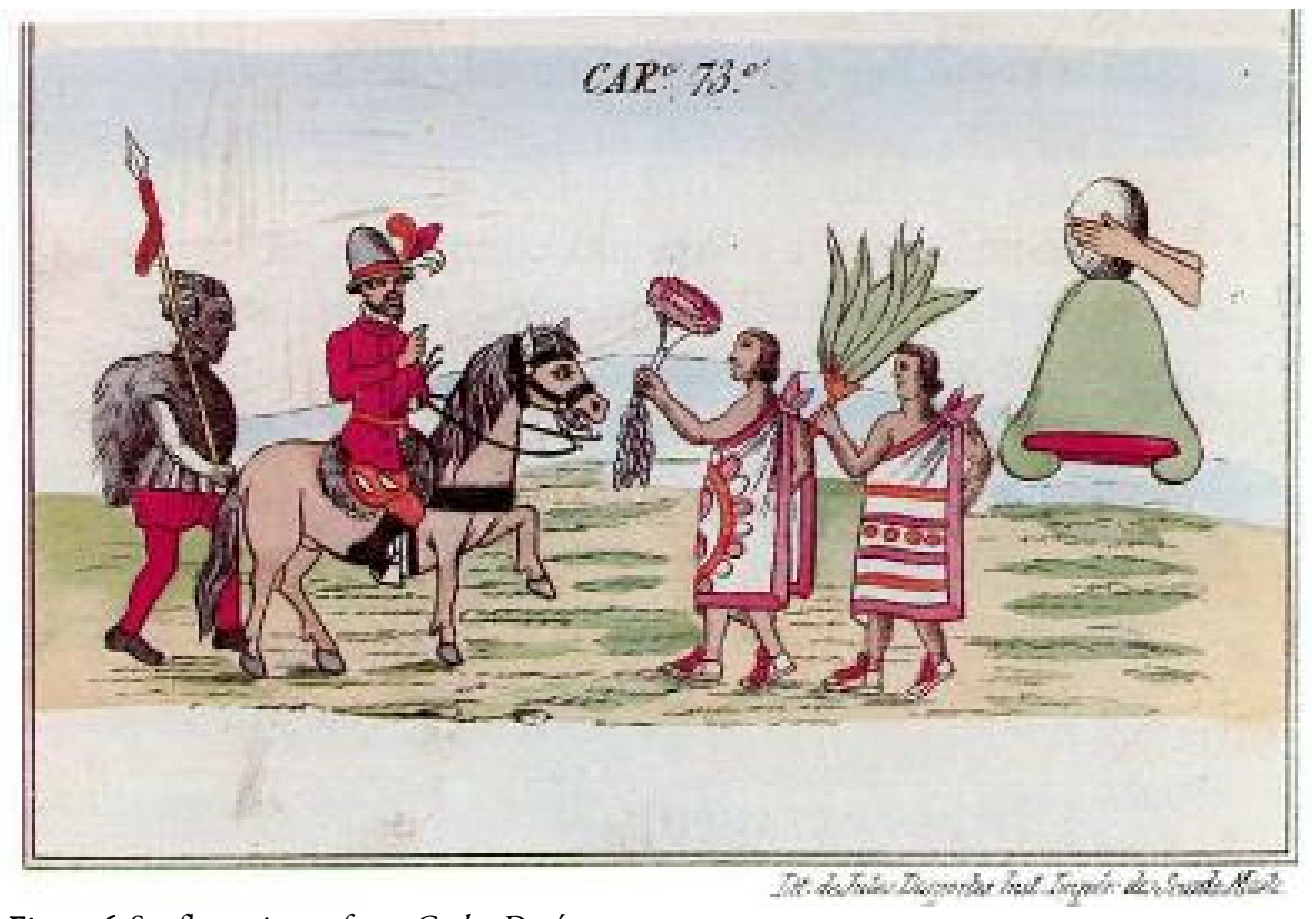

Figure 6. Sunflower image from Codex Durán

Source: https://www.mexicolore.co.uk/aztecs/flora-and-fauna/sunflower

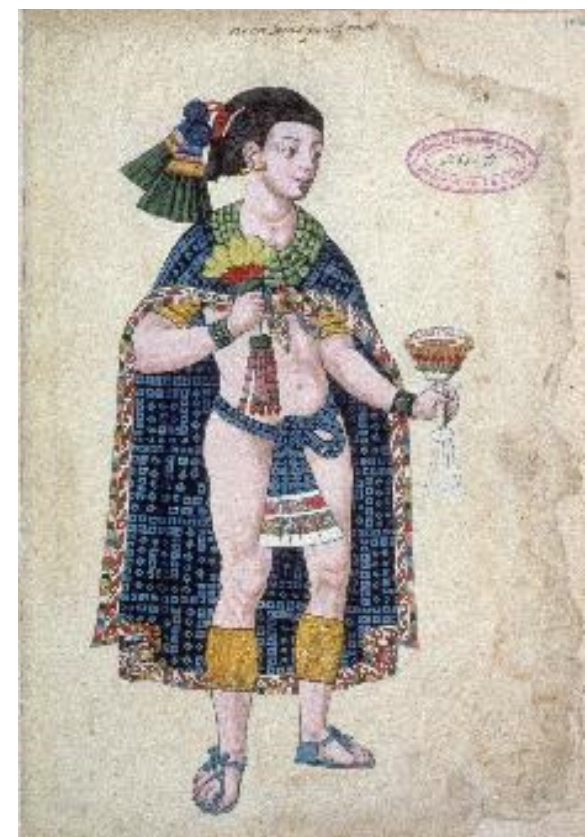

Figure 7. Sunflower image from Codex Ixtlixochitl

Source: https://www.mexicolore.co.uk/aztecs/flora-and-fauna/sunflower 


\section{Sixteenth Century European Sources}

\section{Rembert Dodoens}

The first published European illustration of sunflower appears in a 1568 herbal published in Antwerp entitled Florum, et coronarium odoratarumque nonnudllarum herbarum historia by Rembert Dodoens (15171585), a Flemish botanist and physician. Between 1574 and 1578 he served as court physician to the Emperors of the Holy Roman Empire. Maximilian II and Rudoph II. The woodcut of the sunflower plant (Figure 8) in Dodoen's herbal shows a single stem and a large head. Dodoens named it Chrysanthemum peruviana and described it as "crowned with flowers of exceptional size, a native to Peru and other areas." This implication that it was native to Peru is obviously incorrect since sunflower, is not indigenous to South America. As Dodoens had never been in the New World his assumption of a Peruvian origin is second-hand and not to be trusted. One explanation for the association with Peru is that Spanish ships returning to Spain in the $16^{\text {th }}$ century after the conquest of the Incas by Francisco Pizarro carried gold and silver transported by mules across the isthmus of Panama. Sunflower seeds carried by these ships might have been assumed to originate in Peru. The association of sunflower with Peru was copied in many subsequent European herbals including those of Andrea Caesalpino (1583), Pier Andrea Mattioli (1586), Jacob Dietrich [Tabernaemontanus] (1588), and John Gerard $(1597,1633)$.

8. The first printed image of sunflower in Europe

Source: Dodoens 1568

\section{Voynich Codex}

The bizarre Voynich Codex often referred to as the most mysterious book in the world was discovered in an Italian Catholic college in 1912 by the Polish book dealer Wilfrid Voynich. It now resides in the Beinecke Rare Book and Manuscript Library of Yale University in the US. The handwritten text in a symbolic language that has so far defied translation. In 1944, the Reverend Dr. Hugh O'Neill, a botanical taxonomist on staff of the Catholic University at Washington DC identified a sunflower, Heliantthus annuus, on folio 93r. This identification was confirmed by Tucker and Talbert (2013), Tucker and Janick (2016,2019), and Janick and Tucker (2018). The phytomorph had a single stem and a prominent seed head with suggestions of ray flowers 
indicating it was a domesticated sunflower (Figure 9). This identification along with other New World plants and animals provided evidence that the Voynich Codex had to be post-Columbian and not from the $15^{\text {th }}$ century as was previously assumed. Illustrations of three volcanos in the Voynich Codex, resemble those of Mexico. The first botanical illustration of the Voynich Codex, contains the ligated initials of an indigenous Aztec artist, Juan Gerson, and the embedded name of Gasper de Torres, a Spaniard born in Santo Domingo, Master of Students at the Colegio de Santa Cruz in Tlatelolco from 1568 and 1972. This is evidence that the Voynich Codex was a manuscript of New Spain composed during this time (Janick and Tucker, 2018). The manuscript was once in the court of Emperor Rudolph II and contains the signature of Jacobi à Tepenecz, the ennobled name of Jacobus Horčeicky (1575-1622), the imperial chemist and personal physician of the Emperor. It is intriguing that Rembert Dodoens, the author of the herbal containing the first published sunflower, was also court physician of Rudolf II from 1576-1578.

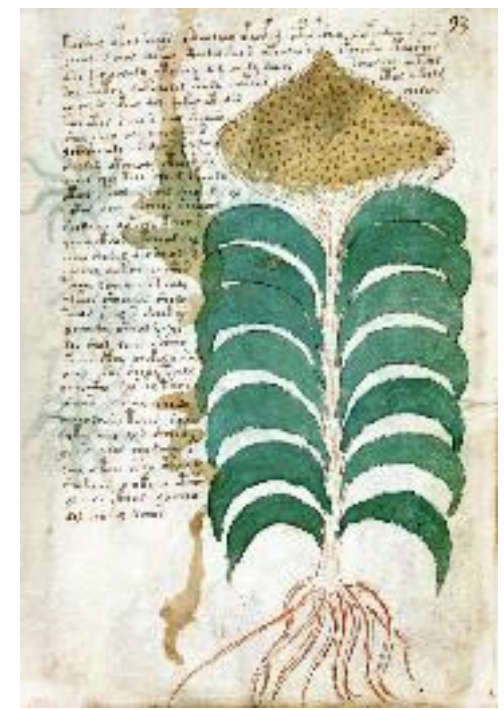

Figure 9. Sunflower from folio 93r of the Voynich Codex

Source: Janick and Tucker (2018)

Theodore de Bry

Theodore de Bry (1528-1598), a Flemish-German engraver, publisher, and editor, was renowned for his depictions of European expeditions to the Americas (Lorant, 1946). An engraving appeared in 1591 illustrating Thomas Harriot's Briefed and True Report of the New Found Land of Virginia, first published in 1588, described the famous 1584 Roanoke expedition financed by Sir Walter Raleigh in what is now North Carolina. John White, artist and mapmaker, painted many scenes of Indian life and served as governor of the colony in 1585, which was rescued by Sir Francis Drake in 1586. The caption of De Bry's engraving of The Town of Sacota mentions gardens and contains six sunflowers, three in flower with large heads, clearly domesticates, and three non-flowering (Figure 10 left and right). The engraving was derived from a painting (Figure 10 middle) of John White that does not contain the garden scene present in De Bry's engraving. De Bry who often modified White's watercolors, added the sunflowers to fill in an empty space. However, sunflowers were mentioned in Harriot's report: "here is also another large herb, which resembles the marigold, about six feet high. The head is a span [about $22 \mathrm{~cm}$ ] in width. Some believe it to be planta solis. From its seeds a kind of bread and also a broth are made." This statement confirms that indigenous farmers in what is now North Carolina grew domesticated sunflowers. However, the source of the sunflower images is unknown but must be based on European $16^{\text {th }}$ century herbal images since John White did not depict sunflower in any of his paintings. 

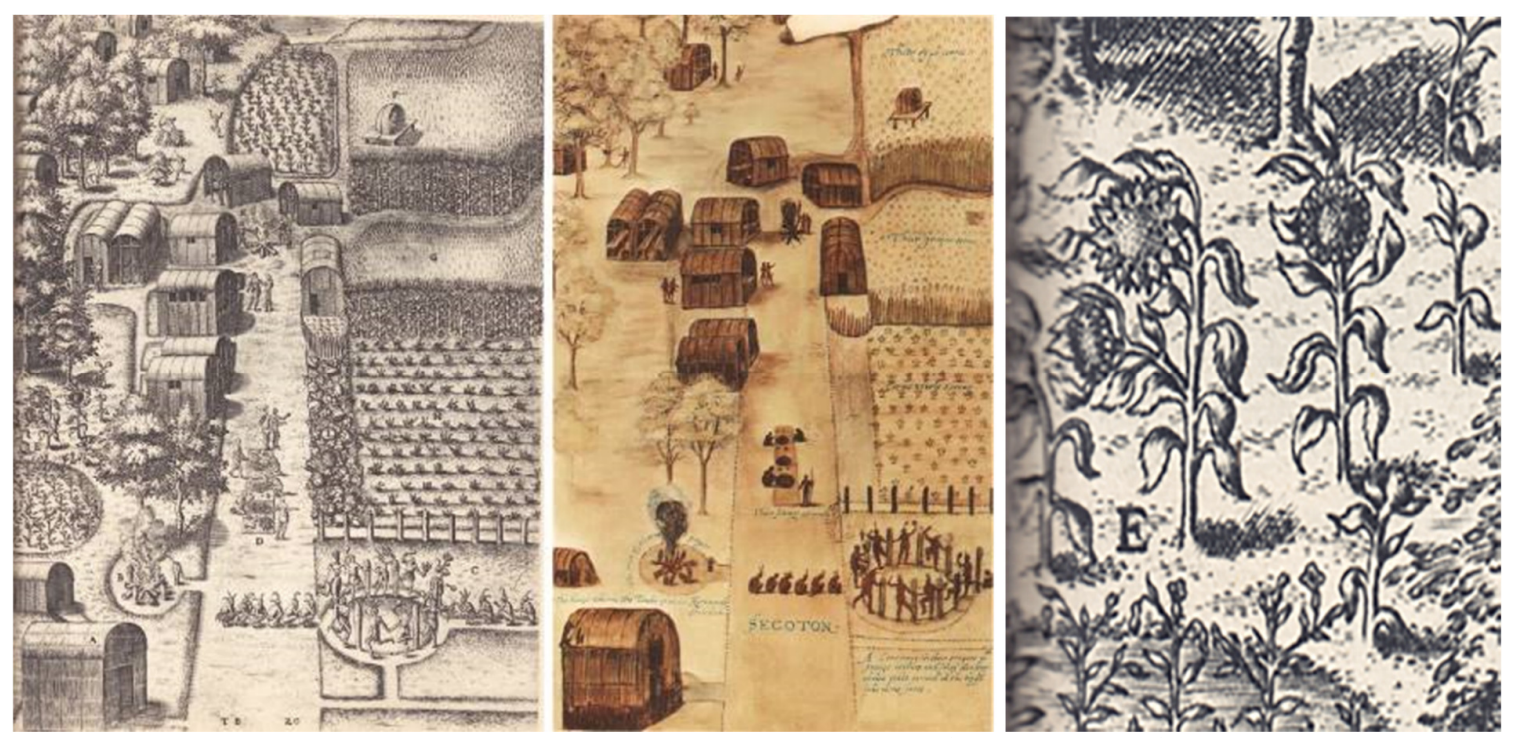

Figure 10. Sunflowers in the 1590 engraving of Theodore De Bry: (left) sunflowers (E) in the Garden of Sacota; (middle) water color of John White; (right) close up of sunflowers Source: Lorant (1946)

John Gerard

John Gerard (Latinized to Gerarde) (1545-1612), a London barber-surgeon, is the author of the bestknown herbal from Renaissance England entitled The Herball or Generall Historie of Plantes published by John Norton in 1597. It contained 1800 illustrated of which most had been previously used by Jacob Dietrich (Jacobus Tabernaemontanus) in his Eicones of 1590. The text was based on an incomplete translation of the Dodoen's Stirpium Historiae Pempates sex (1583) translated from Latin to English by the London physician Robert Priest. Gerard finished the task and reconfigured the arrangement to that of Mathias de l'Obel. Chapter 247 entitled of the flower of the Sunne, or the Marigold of Peru contained 4 images (Figure 11): 1. Flos Solis minor mas, the greater sunne flower; 2. Flos Solis minor femina, the lesser sunne flower; 3. Flos Solis minor mas, the male sunne flower; and 4. Flor Solis minor femina, the marigold sunflower. The first three are domestic sunflowers with large heads and single stems; the fourth branching with small heads may be a wild sunflower but Heiser (1951) could not positively identify it. Gerard mentioned that he had not obtained seed of this type. In Chapter 259 of the 1633 emended edition of Gerard by Thomas Johnson, there are only two images (Figure 12) both of domesticate sunflower: 1. Flor solis major, the greater Sun floure which is identical to the 1586 image of Dodoens; and 2. Flos solis minor the lesser Sunn floure with small leaves surrounding the head. It is unclear why Gerard called it 'lesser' since the head size is similar to the other image. 

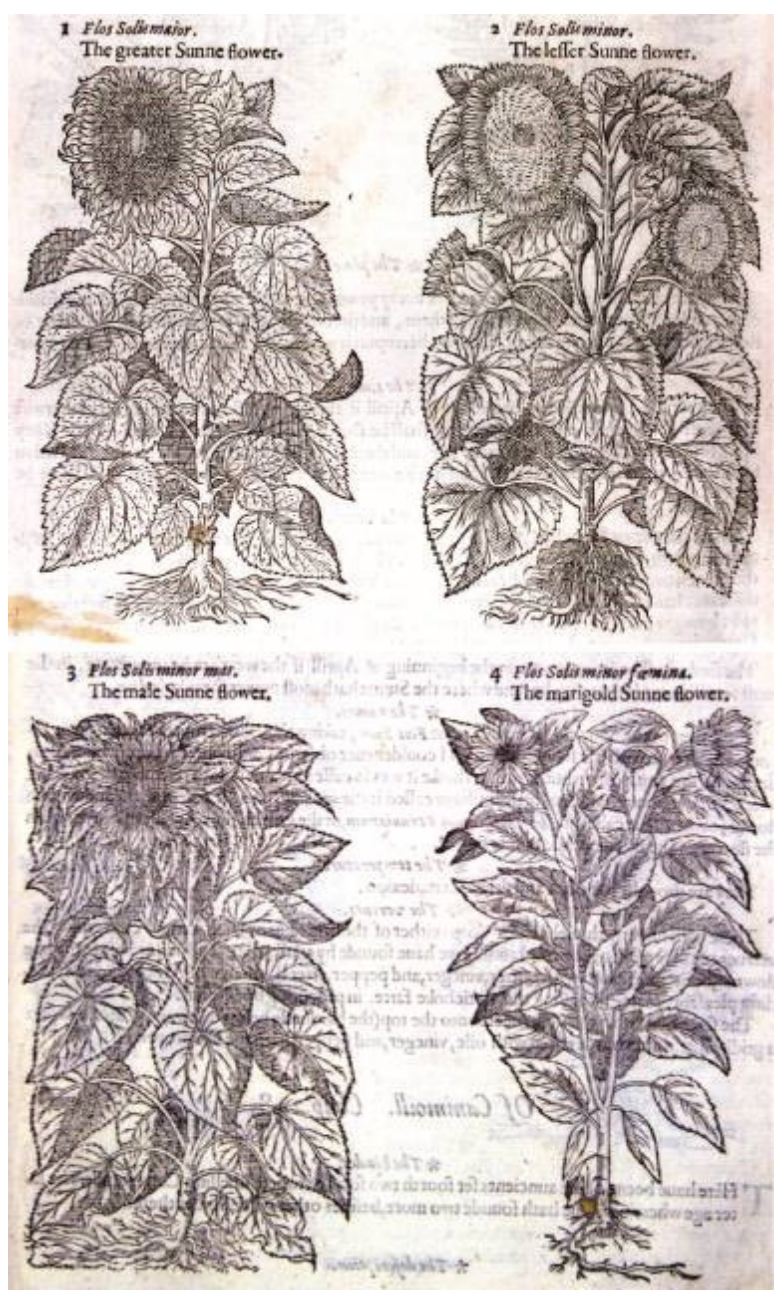

Figure 11. Sunflowers in the 1597 herbal of John Gerard Source: Gerarde (1597)

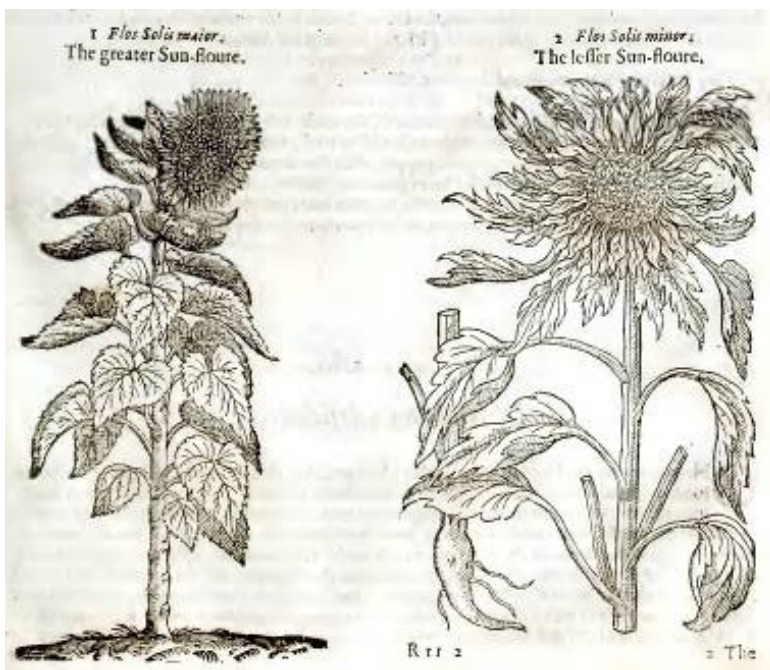

Figure 12. Sunflowers in the 1633 herbal of John Gerard revised and emerged by Thomas Johnson Source: Gerarde and Johnson (1633) 
Francisco Hernández

Francisco Hernández (1514-1587), known as Pliny of the Indies, served as court physician to King Philip II of Spain in 1567. In 1570 he was appointed "General protomedico of our Indies, islands and mainland of the Ocean Sea." Hernández and his son Juan carried out on a seven-year seminal scientific expedition to New Spain to study medical plants. They collected and classified specimens, interviewed native populations through interpreters, supervised indigenous painters, and conducted medical studies (Varey, 2000). His 2500page manuscript covered 3000 plants. The original manuscript and illustrations were destroyed by fire in the Escorial in 1765. However, various portions were already published including a Roman edition in 1651 entitled Rerum Medicarum Novae Hispaniae thesaurus with 683 illustrations. It includes two illustrations of sunflower (Figure 13) with different head sizes, both obviously domesticated. They are labeled chimalacatl, the Nahuatl name for sunflower. They were not based on the original paintings of Hernandez since the lower image is a mirror image of the illustration entitled Flos Solis minor, The lesser Sun floure found in the 1633 edition of Gerard as revised and enlarged by Thomas Johnson (Heiser, 1998). This image is also found in a posthumously published herbal of Nicolas Monardes (1619:195).

The sunflower illustrations in the 1651 Roman edition of Hernandez have been the subject of an exchange between D.L. Lentz and C.B. Heiser (2008). The sunflower illustrations in the 1651 edition are clearly not from the original paintings but have been hijacked from herbal images. However, the original paintings must have represented sunflower since Hernández uses the Nahaatl word chimalacatl. Although the original paintings were destroyed in the 1765 Escorial fire, the linguistic evidence supports Lentz's conclusion that Hernández observed a domesticated sunflower in New Spain.
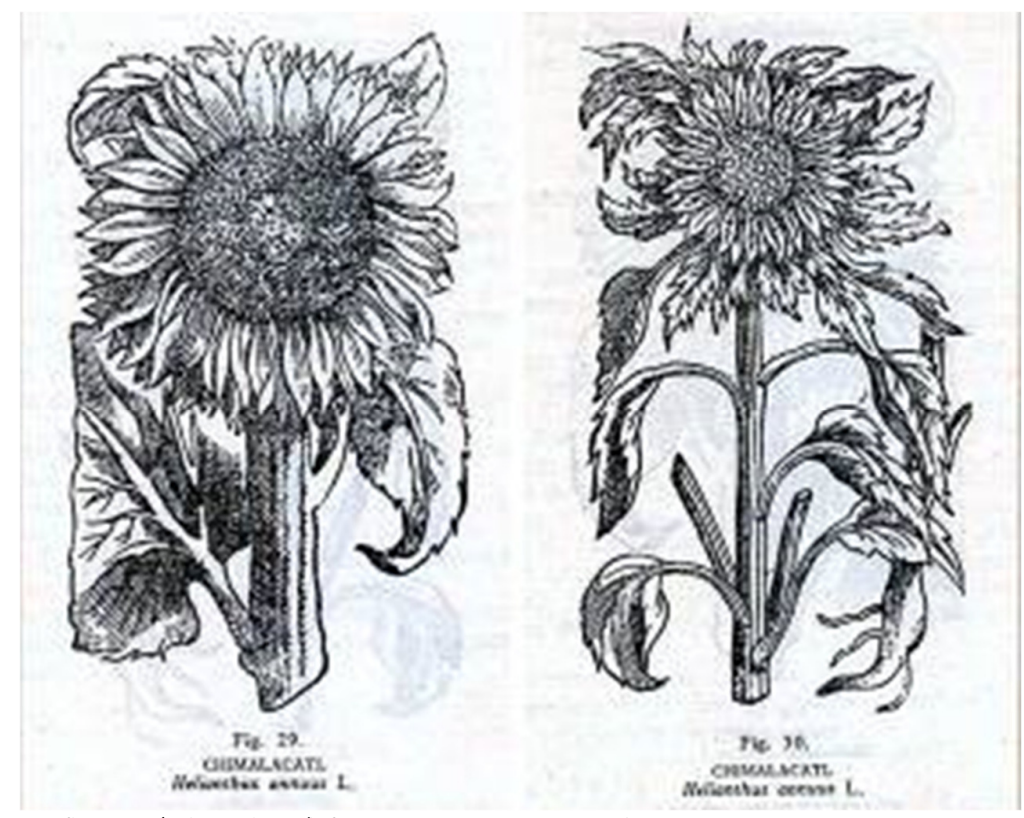

Figure 13. Sunflowers (chimalacat $\$ from Francisco Hernandez Source: Hernández et al. (1651) 


\section{Discussion}

Images of domesticated sunflower are found in a pre-Hispanic Mexican stone sculpture and in various $16^{\text {th }}$ century illustrations in New Spain (present day Mexico) including the works of Sahagún, Diego Durán, the Codex Ixerxochitl, and the Voynich Codex, as well as the European herbals by Rembert Dodoens (1568), Andrea Caesalpino (1583), Pier Andrea Mattioli (1586), Jacob Dietrich 1586, and John Gerard (1597, 1633). A 1590 engraving containing sunflowers by Theodore de Bry illustrates the Roanoke colony in present day North Carolina, but this illustration is derived from European herbal images. It is probable that all $16^{\text {th }}$ century herbal images of sunflowers derive from seed imported to Spain on ships leaving Mexico even though some herbal names suggest (incorrectly) that a Peruvian origin. Until the date of the first sunflowers introduction to Spain becomes known, it remains uncertain whether the origin of these seed was present-day Mexico or United States since Spanish conquistadors in the $16^{\text {th }}$ century made forays from Florida to California, and much of that area became part of New Spain.

Heiser (1955) acknowledged that domesticated sunflower was known in $16^{\text {th }}$ century Mexico, but eventually concluded that there was no evidence that sunflower was present in Mexico in prehistoric or nearly historical times and furthermore that the sunflower only reached Europe from what is now the southeastern United States (Heiser, 2008). These conjectures are not supported by archeological evidence from the Cuevo del Gallo, Mexico (Lentz et al., 2008) or the pre-Hispanic stone sculpture of sunflower (Figure 3). There is abundant linguistic and iconographic evidence that domesticated sunflower were well known in $16^{\text {th }}$ century Mexico. Furthermore, the Peruvian name given by Dodonus in 1568 is strong evidence that the sunflower he observed derived from seed imported on Mexican ships. In addition, the use of the Nahuatl names chimatacatl by Sahagún and Hernandez indicate that the sunflower they observed were well known by Aztecs previous to the conquest by Cortés in 1522 .

\section{Conclusions}

The iconographic evidence cannot differentiate between an independent sunflower domestication in Mexico and a pre-Hispanic migration of domesticated plants from North America. While there is evidence of domesticated sunflower in Mexico from Cuevo del Gallo it cannot be ascertained from the iconographic evidence if these stemmed from selection from independent mutations in Mexico or represent a humaninduced southern migration from Eastern North America. Molecular work by Blackman et al. (2011) on three alleles associated with domesticated sunflowers: 449739 (chorismate syntheses), HaFT1 (floral inducer), HaGA204 (converting gibberellic acid to an inactive form affecting flowering time and head diameter), were not found in wild sunflower populations in Mexico. Furthermore, all domesticated sunflower presently grown in Mexico are descended from the same cultivated genetic lineage as the eastern North American domesticates, indicating that they are recent arrivals. It is however possible there was an independent domestication but that these types have died out or were eliminated by the Spanish friars because of their ceremonial usage. The iconographic evidence taken together indicates domesticated sunflower was present in pre-Hispanic and $16^{\text {th }}$ century New Spain. If domestication only occurred in Eastern North American there must have been preHispanic migration. 


\section{Acknowledgements}

This research received no specific grant from any funding agency in the public, commercial, or not-forprofit sectors.

\section{Conflict of Interests}

The author declares that there are no conflicts of interest related to this article.

\section{References}

Blackman BK, Scascitelli M, Kane NC, Luton H, Rasmussen DA, Bye RA, ... Rieseberg LH (2011). Sunflower alleles support single domestication center in Eastern North America. Proceedings of the National Academy of Sciences 108(34):14360-14365. https://doi.org/10.1073/pnas.1104853108

Caesalpino A (1583). De Plantis libri xvi... Florentiae, Apud. Georgium Marescottrum.

Dietrich J [Tabernaemontanus) (1588). Neuw Kreuterbuch... Frankfurt am Mayn.

Dodoens (Dodonaeus) R (1568). Florum, et coronarium odoratarumque nonnudllarum herbarum historia. Antverpiae, Ex officina Christophori Plantini.

Duke JA (1983). Helianthus annuum L. In: Handbook of energy crops (unpublished). www.hort.purdue.edu/newcrop

Durán D (1581). History of the Indies of New Spain. https://www.mexicolore.co.uk/aztecs/flora-and-fauna/sunflower Gerarde J (1597). The herbal or general history of plants. John Norton, London.

Gerarde J, Johnson T (1633). The herbal or general history of plants... very much revised and enlarged by Thomas Johnson. Adam Islip, Joice Norton and Richard Whitakers. (Reprinted 1975, Dover, Mineola, MN).

Heiser CB (1951). The sunflower among the North American Indians. Proceedings of the American Philosophical Society 95(4):432-448. https://www.jstor.org/stable/3143283

Heiser Jr CB (1955). The origin and development of the cultivated sunflower. American Biology Teacher 17(5):161-167. https://doi.org/10.2307/4438706

Heiser CB (1976). The sunflower. University of Oklahoma Press. Norman, Oklahoma.

Heiser CB (1998). The domesticated sunflower in old Mexico? Genetic Resources and Crop Evolution 45(5):447-449. https://doi.org/10.1023/A:1008603501401

Heiser CB (2008). How old is the sunflower in Mexico? Proceedings of the National Academy of Sciences 105(30):E48E48. https://doi.org/10.1073/pnas.0804588105

Heiser CB, Lentz DE (2008). Comment: Sunflowers among Aztecs? Reply to Heizer. International Journal of Plant Scientists 169(7):980.

Hernandez F, Celsi F, Colonna F, Deversini B, Faber J, Greuter J, ... Terentius J (1651). Rurum medicarum, Novae Hispaniae Thesaurus, seu, Plantarum animalium Mexicanorum historisa. Vitalis Mascari, Romae.

Kutschera U, Briggs WR (2016). Phototropic solar tracking in sunflower plans: an integrative perspective. Annals of Botany 117(1):1-8. https://doi.org/10.1093/aob/mcv141

Janick J, Tucker AO (2019). Unraveling the Voynich Codex. Springer, Cham, Switzerland.

Lentz DL, Pohl MD, Pope KO, Wyatt AR (2001). Prehistoric sunflower (Helianthus annuus L.) domestication in Mexico. Economic Botany 55(3):370-376.

Lentz DL, Pohl MD, Alvarado JL, Tarighat S, Bye R (2008). Sunflower (Helianthus annuus L.) as a pre-Columbian domesticate in Mexico. Proceedings of the National Academy of Sciences 105(17):6232-6237. https://doi.org/10.1073/pnas.0711760105

Lorant S (1946). The New World: The first pictures of America. Duell, Sloan \& Pearce, New York.

Mattioli P (1586). Kreuterbuch... Getruclkt zu franckfurt am Mayn.

Mexicolore (2020). Sunflower. https://www.mexicolore.co.uk/aztecs/flora-and-fauna/sunflower

Mancoff DA (2001). Sunflowers. Art Institute of Chicago, Thames \& Hudson.

Molina de Alonso (1571). Vocabulario en lengua castellana y Mexican. En casa de Antonio de Spinosa, Mexico. 
Monardes N (1574). Primera y segunda y tercera partes de la, que sirven en medicina; Tratado de la Piedra bezaar, y dela yerva escuerçonera; Dialogo de las grandezas del hierro, y de su virtude medicinales. Alonso Escrivano. Sevilla.

Monardes N (1619). Historie des simple medicamens apportes de l'Ammerique, desquels on se sert en la medicine... Lyon. O’Neill H (1944). Botanical observations on the Voynich MS. Speculum 19:226.

Pilorgé E (2020). Sunflower in the global vegetable oil system: situation, specificities and perspectives. OCL-Oilseeds and fats, Crops and Lipids 27:34. https://doi.org/10.1051/ocl/2020028

Sahagún B de (1951-1982). Florentine Codex. General history of the things of New Spain. [1540-1585] 12 vol. Trans. AJO and Anderson CE Dibble. Salt Lake City: University Utah Press.

Seiler GJ Gulya TJ (2016). Sunflower: Overview. Encyclopedia of Food Grains pp 247-253. http//2 nd ed.//dx.doi.org/10.1016/B978-0-12-394437-5.00027-9

Statista (2020). Worldwide oilseed production in 2019/2020, by type (in million metric tons). Retrieved 2020 January 31 from www.statista.com

Tucker AO, Talbert RH (2013). A preliminary analysis of the botany, zoology, and minerology of the Voynich manuscript. Herb News, Austin, TX, USA.

Tucker AO, Janick J (2016). Identification of the phytomorphs in the Voynich codex. Horticultural Reviews 44:1-64.

Tucker AO, Janick J (2019). Flora of the Voynich Codex: An exploration of Aztec plants. Springer, Cham, Switzerland.

Varey S (2000). The Mexican treasury: The writings of Dr. Francisco Hernandez. Stanford University Press. Stanford, California.

Zukovsky PM (1950). Cultivated plants and their wild relatives. 1962 translation from Russian. Commonwealth Agricultural Bureaux. Farnham Royal, Bucks, England.
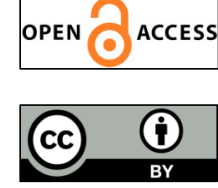

The journal offers free, immediate, and unrestricted access to peer-reviewed research and scholarly work. Users are allowed to read, download, copy, distribute, print, search, or link to the full texts of the articles, or use them for any other lawful purpose, without asking prior permission from the publisher or the author.

License - Articles published in Notulae Botanicae Horti Agrobotanici Cluj-Napoca are Open-Access, distributed under the terms and conditions of the Creative Commons Attribution (CC BY 4.0) License.

(c) Articles by the authors; UASVM, Cluj-Napoca, Romania. The journal allows the author(s) to hold the copyright/to retain publishing rights without restriction. 